Commonwealth Government has now published a two-sheet map of Antarctica by Mr. E. P. Bayliss (Department of External Affairs, Canberra. With handbook. $7 s, 6 d$.). The map is on an azimuthal equidistant projection and has a latitudinal scale of 1:7,500,000. Known land, revised to the most recent discoveries, is shown in brown with valley glaciers in blue. Prominent peaks and heights in metres are shown. The ocean is blue, with soundings and bathymetrical contours. The names of the chief discoverers of lands are shown, and the territorial claims are indicated on the main map and on a smaller scale inset which shows relation with the southern continents. The recently claimed Norwegian sector is not marked as such. The coastal areas of the Australian Antarctic Territory are shown on another inset on a scale of $1: 5,250,000$. On many coasts the tendency to replace the term 'land' by 'coast' has been followed, but where no general name exists the multiplicity of 'lands' remains. The map is an excellent piece of work, with much detail, and is clearly printed. It should prove a standard map for some time. The accompanying handbook gives an account by Mr. J. S. Cumpston of recent exploratory works and cites most, but not all, of the authorities and explorers' records. It contains also an index to the map.

\section{Pasteur Institute of India, Kasauli}

IT is announced in the thirty-eighth annual report of this Institute, recently issued, that the anti-rabic treatment which has been carried on here for forty years has been transferred to the Central Research Institute, Kasauli. The Kasauli Pasteur Institute was formally opened for the treatment of dog-bite and similar cases in August 1900 under Major David Semple, R.A.M.C. It was the first Pasteur Institute to be established in the British Empire; in the first year 321 persons were treated, and the numbers increased year by year until in 1938 more than 22,000 persons received treatment. During its last year, 1938, 20,377 Asiatics and 1,817 Europeans received anti-rabic treatment at Kasauli and its associated centres, with 73 deaths, a mortality of 0.33 per cent, the lowest figure during its long history.

\section{Demography of Eire}

According to the recently published returns of the March quarter, the marriages registered in Eire during this period numbered 3,509 , which was equivalent to an annual rate of 4.7 per thousand of the estimated population, this rate being equal to that for the corresponding quarter of 1939. The number of births amounted to 14,110, of which 7,228 were of males and 6,882 of females. This represents a rate of $19 \cdot 1$ per thousand of the population, being 0.3 below the rate for the first quarter of 1939. The total included 460 illegitimate births, equivalent to $3 \cdot 3$ per cent of the to $2 ?$ births recorded. The number of deaths registered .... ing the quarter was 13,376 , of which 6,887 wer of ales and 6,489 of females. The equivalent annual ra: , was $18 \cdot 1$ per thousand of the estimated population, being 0.1 below the rate for the first quarter of the preceding year.

\section{Juvenile Literature}

"500 Books for Children", by Nora E. Beust (Washington, D.C., 15 cents), is a pamphlet with a sound idea behind it. Capable selections from the present overgrown jungle of books are a great help, if not a necessity. The list is well arranged in three sections of advancing age and indexed with crossreferences. With a host of new books, old favourites still keep their places, such as Kingsley's "Heroes", "Treasure Island", and Kipling's "Mowgli" and "Just So" stories. We looked for some time for the two immortal "Alices" and at last found them under C. L. Dodgson, who never would admit that he wrote them. Animals, flowers and Nature in general are well represented. Children can even get an idea of what happens inside the atom. The illustrations show two designs which have won special medals.

\section{Announcements}

GENERAL DE GAULLE, leader of the French Volunteer Legion, has appointed M. André Labarthe director-general of all French services connected with armaments and scientific research in Great Britain. M. Labarthe, who is thirty-eight years of age, has appealed to French engineers, men of science, and industrial workers to join the already large number of their colleagues who have enlisted as civilian workers in the Legion.

THE Minister of Labour and National Service has appointed Sir William Beveridge, master of University College, Oxford, and formerly director of the London School of Economics and Political Science, as commissioner to survey the available resources of man-power of all kinds and to report thereon with suggestions on the means by which these resources can be utilized fully for national purposes. The office of the survey will be at the Ministry of Labour and National Service, Montagu House, S.W.1, and Mr. A. Reeder, deputy director of statistics in the Ministry, will act as secretary to the survey.

THE Summer School in Social Biology arranged by the Educational Advisory Board of the British Social Hygiene Council, which was to have taken place at Westminster College, Cambridge, during August 1-8, has been postponed until the advent of more favour. able circumstances.

Dr. Charles Slater, consulting bacteriologist to St. George's Hospital, London, who died on March 15 , bequeathed $£ 10,000$ to St. George's Hospital for teaching bacteriology or research work in that science, $\mathfrak{f 5 , 0 0 0}$ to the University of Manchester for the equipment and maintenance of the laboratories, and $£ 4,000$ to the University of Cambridge for teaching or research work in medical science. 